\title{
PERLINDUNGAN PEMODAL REKSADANA MELALUI GOOD CORPORATE GOVERNMENT (STUDI KASUS BANK GLOBAL)
}

\author{
Agam Sulaksono \\ Fakultas Hukum Universitas Wijaya Kusuma Surabaya \\ e-mail:agamsulaksono@yahoo.com
}

\begin{abstract}
ABSTRAK
Pasar modal merupakan tempat untuk bertemu antara pembeli dan penjual dalam penjaminan perdagangan seperti saham dan obligasi sebagai sumber-sumber nilai ekonomi yang saling menguntungkan. Oleh karenanya nilai dari dana yang dijaminkan bersama dari investasi manajer adalah tinggi dan kemudian efek yang baik dari issu tersebut untuk dasar penunjang bisnis yang lebih baik yaitu melalui penerapan prinsip-prinsip pelaksanaan perusahaan yang baik.

Kata Kunci: keterbukaan, dapat dipercaya, jujur, mandiri dan bertanggung jawab.

ABSTRACT

The capital market is a place of meeting sellers and buyers to trade securities such as stocks and bonds as a source of economic value of mutual funds. So that the value of mutual fund securities of the Investment Manager is high then the effect should be good in this case the issuer is required on an ongoing basis to spur business with the better through the application of the principles of good corporate governance.
\end{abstract}

Keywords: transparancy, accountability, fairness, independency, dan responsibility.

\section{PENDAHULUAN}

Dalam perekonomian modern keberadaan pasar modal merupakan suatu kebutuhan negara-negara yang ekonominya maju. Pasar modal yang berwujud Bursa Efek seperti juga lembaga perbankan, memainkan peranan penting. Pasar modal sebagai barometer perekonomian suatu negara menunjukkan aktivitasnya. Pasar modal menjadi petunjuk bagaimana Emiten dan pemodal reksadana berinteraksi secara tidak langsung dalam kegiatan ekonomi. Emiten diwakili oleh perusahaan go public mencari dana melalui pasar modal sedangkan pemodal reksadana menginvestasikan uangnya, juga dengan memasuki pasar modal. Dalam hal ini investasi dari pemodal reksadana harus melalui perantara yaitu perseroan yang telah mempunyai ijin reksadana sesuai Pasal 18 ayat 4 Undang-Undang Penanaman Modal maupun melalui Manajer Investasi sesuai Pasal 18 ayat 5 UUPM. Dana yang terkumpul diakumulasikan pada sektor riil sebagai tolok ukur berkembang atau menurunnya perekonomian suatu masyarakat. Tingkat perekonomian ditunjukkan oleh indeks pasar modal yang setiap hari berubah seiring aktivitas perekonomian emiten secara keseluruhan.

Pasar modal merupakan sarana pertemuan penjual dan pembeli memperdagangkan saham dan obligasi, dalam hal ini juga dikenal saham yang diterbitkan reksadana berbentuk perseroan terbuka atau open end, yang dilaksanakan melalui bursa efek sesuai Pasal 19 UUPM perseroan tertutup atau closed end.

Bursa efek tidak lain merupakan sebuah pasar tempat diselenggarakan perdagangan efek. Pengertian pasar diibaratkan layaknya sebuah pasar yang memperdagangkan barang kebutuhan pokok seharihari seperti sayur-mayur dan kebutuhan pokok manusia lainnya. Dalam pasar tersebut juga terdapat efek yang tidak ditawarkan di bursa yaitu saham reksadana berbentuk perseron tertutup atau close end. Sedangkan reksadana berbentuk Kontrak Investasi Kolektif tidak menawarkan saham dan obligasi tetapi memperdagangkan Unit Penyertaaan sesuai Pasal 20 UUPM.

Dalam pengelolaannya Manajer Investasi menawarkan instrument efek yang merupakan barang namun mutunya tidak dapat dilihat secara kasat mata kepada para pemodal reksadana. Karena fungsi reksadana sebagai sarana investasi secara tidak langsung, maka bursa efek wajib menyediakan fasilitas pendukung untuk melakukan pengawasan dan perdagangan bagi Manajer Investasi. Selain itu bursa diharapkan membuat fasilitas untuk mendukung jalannya perdagangan reksadana misalnya penyediaan papan pengumuman berisi indeks Nilai Aktiva Bersih. 
Bursa juga mempunyai ciri yang sama dengan pasar tradisional yaitu tempat berkumpulnya pembeli dan penjual yang akan mempertemukan sisi penawaran dan permintaan barang dagangan. Berbeda dengan pasar pada umumnya, akses ke bursa efek hanya dibatasi bagi perantara pedagang efek yang telah menjadi anggota bursa, dapat masuk untuk melakukan pembelian atau penjualan saham dan obligasi .

Untuk menjadi anggota bursa efek selain harus mempunyai akses ke dalam sistem perdagangan juga harus menjadi pemegang saham pada bursa tersebut sesuai Pasal 1 angka 2 UUPM. Mereka yang tidak merupakan anggota bursa hanya dapat menitipkan apa yang diperdagangkan tersebut kepada anggota bursa yang merupakan perantara perdagangan efek.

Dalam hal ini Manajer Investasi melakukan pembelian efek dari penjual, melalui pasar primer maupun pasar sekunder. Istilah penjual pada pasar tradisional bisa diartikan sebagai pihak yang menawarkan barangbarang emiten selanjutnya diperdagangkan di bursa. Pasal 1 ayat 6 UU PM menyatakan bahwa emiten adalah pihak yang melakukan penawaran umum. Emiten merupakan pihak yang mengeluarkan efek berupa saham atau obligasi yang ditawarkan kepada masyarakat.

Setelah penawaran umum dilakukan, pada dasarnya emiten tidak mempunyai hubungan lagi dengan efek yang dikeluarkan tersebut. Karena naik turunnya harga efek tergantung kepentingan pemodal, antara lain Manajer Investasi yang melakukan jual beli atas efek tersebut. Emiten hanyalah berkewajiban mengelola usahanya dengan baik dan menjalankan kewajiban-kewajibannya sebagai perusahaan Go Public. Pada akhirnya kinerja emiten juga berdampak pada harga efek tersebut. Harga efek memang akan dipengaruhi oleh kinerja emiten dalam menjalankan aktifitas usahanya, bukan karena campurtangannya di dalam pasar modal. Jadi pasarlah yang diharapkan akan menentukan harga efek tersebut berdasarkan faktor resiko usaha. Salah satu komponen yang menentukan harga efek adalah berupa informasi secara terus-menerus disampaikan oleh emiten mengenai kegiatan usahanya kepada pemegang saham (pemodal reksadana).

Istilah emiten harus dipisahkan dari pengertian perusahaan go public karena asal-usulnya berbeda. Pemberian nama emiten karena perusahaan melakukan emisi atau mengeluarkan Efek dalam suatu penawaran umum sedangkan perusahan publik menjadi go public bukan karena secara sengaja melakukan penawaran efek kepada masyarakat dalam suatu penawaran umum. Dinamakan perusahaan publik sebab telah memenuhi kriteria tertentu seperti ditetapkan oleh UUPM, yaitu perseroan terbatas yang sahamnya telah dimiliki sekurang-kurangnya oleh tiga ratus pemegang saham dan memiliki modal disetor sekurang-kurangnya tiga milyar rupiah. Atau suatu jumlah pemegang saham dan modal disetor yang ditetapkan oleh Peraturan Pemerintah sesuai Pasal 1 angka 22 UUPM.

Dari fenomena perbedaan ini terlihat bahwa perusahan dapat menjadi Go Public karena proses berjalannya waktu. Antara lain perusahan telah berdiri secara turun temurun dan akhirnya saham dimiliki satu keluarga hingga mencapai 300 (tiga ratus) orang. Dapat pula terjadi pemilik perusahan telah membagikan sahamnya kepada pegawai yang berprestasi hingga mencapai 300 (tiga ratus) pemegang saham. Pada sisi lain arti kata emiten adalah status yang didapat karena adanya penawaran umum efek seperti saham atau obligasi.

Banyak alasan yang dilakukan emiten untuk mengadakan penawaran umum kepada masyarakat. Antara lain alasan yang sifatnya ekonomis yaitu mendapatkan dana baik untuk pengembangan perusahaan ataupun membayar hutang. Alasan ini menjadi utama karena dengan penawaran umum dianggap sebagai cara mendapatkan dana relatif murah dibandingkan permodalan dari sumber lain misalnya perbankan. Kenyataan ini diperkuat bahwa dana murah tidak hanya akan didapatkan sekali saja, tetapi pada masa yang akan datang emiten tetap akan mempunyai kesempatan mendapatkannya kembali. Dengan kata lain emiten yang telah melakukan penawaran umum akan mempunyai akses yang lebih mudah terhadap permodalan.

Penawaran umum juga merupakan suatu cara untuk meningkatkan publisitas emiten. Prosedur kegiatan yang dilakukan sebelum penawaran umum, Emiten harus mengiklankan diri dengan mengeluarkan prospektus dan melakukan road show untuk menjual efeknya. Jatidiri emiten yang telah melakukan penawaran umum akan terus terpublikasi antara lain melalui quotation secara terus-menerus atas harga saham dan obligasi di Bursa Efek. Emiten akan mendapatkan porsi pemberitaan yang sering daripada perusahaan tertutup atau yang belum melakukan penawaran umum. Pemberitaan mengenai harga saham dan obligasi diumumkan selain melalui bursa juga media lainnya seperti surat kabar maupun televisi.

Akibat lebih lanjut bagi emiten yaitu mendapatkan promosi gratis secara terus-menerus, baik untuk produk maupun image di masyarakat. Pengamat dan 
analis keuangan secara berkala akan melakukan observasi serta penganalisaan mengenai keadaan emiten baik untuk masyarakat umum maupun untuk kepentingan Manajer Investasi yang aktif berinvestasi di pasar modal. Analisa ini tentunya tidak hanya menyangkut hal-hal baik saja dari emiten tetapi juga atas keadaan lain yang kurang menguntungkan bagi perusahaan. Tulisan ini akan memacu emiten untuk menjalankan perusahaannya dengan cara yang makin baik dan pada akhirnya akan meningkatkan prinsip-prinsip Good Corporate Governance.

Selain keuntungan di atas, keputusan untuk melakukan penawaran juga dapat menimbulkan kerugian atau lebih tepat kesulitan-kesulitan terhadap emiten. Tuntutan publik yaitu adanya keterbukaan tidak hanya menyebabkan kewajiban untuk memberikan laporan keuangan yang harus diaudit setiap semester hingga akhir tahun. Dalam hal ini emiten juga mempunyai kewajiban dari waktu ke waktu maupun secara periodik melakukan ekspose laporan ke masyarakat melalui media massa. Pelaksanaan semua kewajiban ini pada akhirnya akan mengakibatkan terjadinya pembengkakan biaya.

Setelah menjadi perusahaan go public, maka dalam melakukan tindakan tertentu yang sifatnya mempunyai perbenturan kepentingan mengharuskan adanya pendapat dari profesi penunjang dan meminta persetujuan dari pemegang saham lainnya atas tindakantindakan tersebut. Ketentuan ini diatur dalam angka 6h Peraturan BAPEPAM Nomor X.E.J tentang Benturan Kepentingan jo Peraturan BAPEPAM Nomor X.E.2 tentang Transaksi Material dan Perubahan Kegiatan Usaha. Kewajiban-kewajiban keterbukaan dan persetujuan pemegang saham seperti ini tentunya tidak akan ditemui apabila tetap menjadi perusahaan tertutup. Karena mereka tidak ada keharusan bagi mereka untuk membuat publikasi atas laporan keuangan usahanya.

Dari uraian di atas bahwa menjadi go public merupakan perjalanan sejarah bagi emiten dalam memajukan usahanya. Emiten akan masuk dalam kehidupan yang berbeda daripada perusahaan yang sahamnya masih dipegang kalangan terbatas, seperti pendapat Edward Rock yang menyatakan (Hamud M. Balfas, 2006:23): "a miracle of birth occurs when a company go public, because it happens all the time one take for granted the legal and institutional infrastructure that facilities the transformation of a closely held enterprise in which ownership and management overlap and which participation have continuous access to information into firm in which the supply of information is for more constricted and periodic"
Sesuai Pasal 93 Undang-Undang Pasar Modal menyatakan bahwa: "Setiap pihak dilarang dengan cara apapun membuat pernyataan atau memberikan keterangan yang secara materiil tidak benar atau menyesatkan sehingga mempengaruhi efek di bursa efek ....".

Dari ketentuan tersebut adanya kewajiban membuat pernyataan dan memberikan keterangan yang benar bukan hanya kewajiban bagi diri emiten, juga semua pihak yang beraktifitas di Bursa Efek antara lain Manajer Investasi. Karena kegiatan Manajer Investasi berfungsi mengumpulkan dana masyarakat maka sebagai sasaran penawaran umum harus memberikan gambaran jelas mengenai apa yang diperjualbelikan tersebut. Dalam Peraturan Nomor IV D.1 yang tertuang dalam Keputusan BAPEPAM Nomor: KEP-19/PM/2004 tentang Iklan Reksadana menyebutkan: "pernyataan atau data tentang iklan suatu reksadana mengenai kinerja reksadana dan Manajer Investasi yang mengelola reksadana tersebut wajib dibuat berdasarkan keterangan atau informasi yang benar tentang fakta materiil yang diperlukan agar tidak memberikan gambaran yang menyesatkan “.

Dalam hal ini masyarakat harus mendapatkan perlindungan hukum dari kemungkinan terjadinya penipuan dari penawaran umum tersebut. Dari hal tersebut terdapat dua alasan bahwa penawaran umum reksadana yang memerlukan campur tangan BAPEPAM. Alasan pertama: adalah nilai ekonomis maksudnya pemodal reksadana perlu mendapatkan keterangan penjelasan serta informasi mengenai apa yang ditawarkan, untuk apa penawaran dilakukan, bagaimana status dan jenis efek yang sedang ditawarkan, siapa yang menawarkan efek, berapa besar penawaran, untuk apa dana yang akan ditawarkan dan akhirnya apa yang akan didapat dengan penawaran tersebut di masa yang akan datang. Prinsip keterbukaan atau transparansi ini dilakukan dengan cara mengeluarkan prospektus yang memungkinkan masyarakat mengetahui segala sesuatu menyangkut penawaran umum tersebut. Prospektus akan memaparkan segala seluk beluk yang menyangkut penawaran umum atas reksadana tersebut. Dengan demikian akan memberikan gambaran bagi calon pemodal untuk pengambilan keputusan yaitu apakah akan membeli atau tidak reksadana yang sedang ditawarkan tersebut.

Alasan kedua: yaitu penegakan hukum, muncul karena adanya potensi kejahatan dalam suatu penawaran umum. Ketentuan ini mewajibkan Manajer Investasi untuk menerapkan prinsip-prinsip keterbukaan, disertai dengan ancaman hukum. Sanksi hukum atas penyajian informasi yang menyesatkan atau mis- 
leading terdapat dalam Pasal 104 Undang-Undang Penanaman Modal: "Setiap pihak yang melanggar ketentuan sebagaimana dimaksud dalam Pasal 90, 91, 92, 93, 95, 96, 97 ayat 1 dan pasal 98 diancam dengan pidana penjara paling lama 10 (sepuluh) tahun dan denda paling banyak Rp.15.000.000.000 (lima belas milyar rupiah)".

Hukum berharap pemodal reksadana mendapatkan perlindungan dari kemungkinan adanya penipuan dalam suatu penawaran umum. Dengan penyajian yang benar dan tidak menyesatkan, pemodal reksadana diharapkan dapat mengambil keputusan yang tepat.

\section{STUDI KASUS REKSADANA YANG BERAKI- BAT PENUTUPAN BANK GLOBAL}

\section{Posisi Kasus}

Belajar dari kasus PT. Prudence Asset Management disingkat PAM sebagai penerbit Reksadana Prudence Mantap dan defaultnya pembayaran obligasi subordinasi yang diterbitkan Bank Global. Bahwa Manajer Investasi yaitu PT. Prudence Asset Manajemen telah mengajukan pernyataan pendaftaran untuk penerbitan surat efektif produk Reksadana Prudence Mantap, yang kemudian diteliti berkas-berkasnya dan disetujui oleh BAPEPAM. Sesuai komentar Kepala Bagian Pengelolaan Investasi dan Reksadana BAPEPAM, Budi Sukamto yang menyatakan bahwa: (Jawa Pos, 14 Desember 2004) "Selama ini ijin PT. Prudence Asset Manajemen sebagai Manajer Investasi untuk produk Reksadana Prudence Mantap dinyatakan mantap dan dikaitkan Bank Global maka persyaratannya komplit dan produk-produk portofolionya bagus".

Selanjutnya Bank Global berkedudukan sebagai Agen Penjual bagi produk reksadana tersebut yang diterbitkan oleh PT. Prudence Asset Manajemen pada Januari 2004. Adapun nama efek yang dikelola dalam Reksadana Prudence Mantap adalah (Jurnal Hukum dan Pasar Modal, 2005:86): “Obligasi I Ultrajaya tahun 1999 seri A, Obligasi Amortisasi WIKA III tahun 2003 seri A, Obligasi Subordinasi I Bank Global 2003, Obligasi HM Sampoerna Tbk tahun 2000, Obligasi Dankos Laboratories I tahun 2000 seri A, Obligasi Indosat I tahun 2001 seri A, Obligasi I Telkom tahun 2002, Obligasi Pupuk Kaltim I tahun 2002 seri A-1, Obligasi Jasa Marga IX tahun 2002 seri N-1, Obligasi Amortisasi Indo Jasa Pratama tahun 2003, dan Obligasi subordinasi seri B Bukopin tahun 2003".

Produk ini telah mengguncang lembaga reksadana karena pada satu sisi mengoleksi portopolio obligasi rekap Bank Global, yang juga berkedudukan sebagai Agen Penjual. Disisi lain produk ini pula yang ikut menyeret PT. Bank Global Internasional Tbk menjadi bank yang bermasalah hingga dilikuidasi.

Pada tahap-tahap awal sebelum dilikuidasi, beberapa pihak menyebutkan bahwa kinerja finansiil Bank Global cukup baik. Hal ini ditandai dengan beberapa indikator misalnya CAR atau Capital Adequate Ratio modal per September 2004 masih 44,84 persen dan pada periode itu Bank Global juga meraih keuntungan. Pada September 2004 laporan keuangan kepada Bursa Efek Jakarta menunjukkan bahwa rasio kecukupan modal Bank itu mencapai 44\%. Apabila diamati kecukupan modal Bank tersebut disebabkan telah menerbitkan Obligasi Subordinasi I Bank Global 2003 yang berasal dari obligasi rekap. Obligasi rekap perbankan penjualannya mulai meningkat pada tahun 2002 tidak terlepas dari dua penyebab. Pertama, penurunan suku bunga Sertifikat Bank Indonesia (SBI) yang berimbas mendorong penurunan suku bunga deposito. Akhirnya deposito menjadi tidak menarik lagi bagi nasabahnya. Kedua, penurunan suku bunga ini menciptakan kondisi ideal bagi pertumbuhan nilai pasar obligasi. Momentum ini sering dimanfaatkan oleh bank-bank rekap untuk menerbitkan obligasi rekapnya. Obligasi rekap adalah berbagai langkah penyelamatan yang dilakukan perbankan dengan cara penjualan obligasi perbankan. (Djoko Retnadi, 2005:50)

Bagi Bank yang intermediasi kreditnya berjalan dengan baik, penurunan suku bunga SBI tidak terlalu berpengaruh. Karena suku bunga kredit atau pinjaman pada umumnya tidak ikut menurun. Sebaliknya bagi Bank dengan porsi kredit yang relatif kecil di dalam asetnya, penurunan SBI ini jelas akan semakin menurunkan pendapatannya. Adanya tekanan penurunan suku bunga pada sisi aktiva dan passiva ini akan mengganggu posisi keuangan Bank.

Bagi bank yang mengalami penurunan hasil investasi akibat penurunan suku bunga SBI harus terus berupaya menurunkan biaya bunga, sekaligus mempertahankan deposannya agar tidak berpindah ke Bank lain yang berani memberikan suku bunga lebih tinggi. Upaya terakhir yang dilakukan Bank adalah menawarkan produk deposito yang dikaitkan dengan obligasi rekap. Maksudnya untuk meningkatkan return dari deposito, mereka menawarkan obligasi rekap sebagai pelaksanaan Pasal 17 Peraturan Bank Indonesia Nomer 2/2/PBI /2000 tentang Penatausahaan dan Perdagangan Obligasi Pemerintah. Bank bekerja sama dengan Manajer Investasi membentuk unit reksadana berbasis obligasi rekap. 
Dalam hal ini Bank Global diberikan kesempatan satu bulan untuk menambah modal. Namun ternyata manajemen tidak melakukan penambahan modal dan akhirnya dibekukan ijin operasionalnya. (Jawa Pos, edisi 17 Desember 2004)

Setelah sebulan sejak membekukan kegiatan PT. Bank Global Internasional, akhirnya Bank Indonesia mencabut ijin usaha Bank berdasarkan Surat Keputusan Gubernur Bank Indonesia nomor: 7/2/KEP-GBI/ 2005 tanggal 13 Januari 2005. Bank Global tetap mengalami kekurangan rasio kecukupan modal (CAR Bank tersebut menjadi negatif 39,11\%). Tindakan penutupan sebuah Bank merupakan sebuah ultimate action yang dilakukan oleh BI. Karena BI menganggap kejadian tersebut dapat membahayakan sistem perbankan nasional, sesuai Pasal 37 ayat 2 UU Nomer 7 tahun 1999 sebagaimana diubah dengan UU Nomor 10 Tahun 1998.

Dari sisi perbankan menurut Deputi Senior Bank Indonesia (waktu itu) bernama Miranda S. Gultom, ada empat alasan yang melatarbelakangi ditutupnya Bank Global. Pertama: terus memburuknya kondisi keuangan bank karena mereka terbukti memperjualbelikan surat reksadana dan memberikan kredit fiktif. Bank Indonesia menemukan sekitar Rp. 30 milyar kredit fiktif dan Rp. 400 milyar obligasi fiktif. Kedua: tidak memberikan tambahan modal yang diminta Bank Indonesia sejak Bank tersebut masuk pengawasan khusus pada 27 Oktober 2004 hingga 13 Desember 2004. Ketiga: Direksi bank tidak menunjukkan itikad baik patuh pada aturan. Keempat: pegawai Bank tersebut berusaha merusak dan menghilangkan dokumendokumen penting bank.

Otoritas Bursa Efek Jakarta pada hari Senin tanggal 17 Januari 2005 menyepakati penghapusan pencatatan efek (delisting) PT. Bank Global International Tbk (kode BGIN). Penghapusan pencatatan efek Bank Global berlaku efektif mulai 18 Januari 2005 terkait dengan pencabutan ijin usaha Bank tersebut oleh Bank Indonesia tanggal 13 Januari 2005. Sebelum turunnya kebijaksanaan tersebut, para nasabah Bank telah beramai-ramai mencairkan tabungan dan deposito. Isu adanya nasabah yang ditolak dalam pencairan deposito, membuat para pemodal Reksadana Prudence Mantap di Bank Global ikut beramai-ramai menarik dana investasinya atau redemption.

Persoalan menjadi semakin runyam karena manajemen Bank Global tidak merasa sebagai agen penjual bagi produk reksadana tersebut. Pihak manajemen tersebut selanjutnya menuduh pada oknum karyawan Bank yang menjual reksadana itu. Akhirnya pihak manajemen Bank menolak mencairkan rek- sadana tersebut. Sementara itu dengan adanya reksadana fiktif yang dipasarkan Bank Global dengan nama Reksadana Prudence Mantap, pihak PT. Prudence Asset Manajemen menganggap bahwa Bank Global telah mencemarkan nama baiknya. Akhirnya pemodal tidak dapat menarik dananya pada PT. Prudence Asset Manajemen. Penarikan dana pengaturannya didasarkan pada Pasal 19 ayat 2 Undang-Undang Penanaman Modal bahwa: "Dalam hal pemegang saham reksadana terbuka melakukan penjualan kembali reksadana terbuka wajib membeli saham-saham tersebut". Demikian pula didasarkan pada Pasal 20 ayat 2 Undang-Undang Penanaman Modal bahwa: "Dalam hal pemegang Unit Penyertaan melakukan penjualan kembali, Manajer Investasi wajib membeli kembali".

Keadaan penarikan dana oleh pemodal pada lembaga reksadana tersebut, dapat terjadi karena runtuhnya perusahaan emiten. Menurut pendapat dari Boediono, bahwa salah satu penyebab runtuhnya perusahaan di Indonesia terhadap gejolak perekonomian adalah lemahnya penerapan Good Corporate Governance dalam pengelolaan perusahaan (Boediono, 2001:57). Jawa Pos telah memberitakan (Jawa Pos, edisi 16 Desember 2004): "Berbagai laporan keuangan yang sempat dipublikasikan oleh Bank Global ternyata telah mengelabuhi banyak pihak diantaranya selain dua institusi tersebut (BI dan BAPEPAM) perusahaan pemeringkat efek yaitu PT. Kastnik Credit Rating Indonesia, yang telah kecolongan karena memberikan obligasi Bank Global peringkat A- (minus), setelah Bank Global menerbitkan obligasi subordinasi senilai Rp. 400,- (empat ratus) milyar yang dicatatkan di Bursa Efek Surabaya pada 11 Juni 2003, obligasi itu ditawarkan pada nilai nominal Rp. 500,- (lima ratus) juta dan jatuh tempo pada 6 Juni 2013".

Demikian pula dengan Kompas telah memberitakan bahwa (Kompas, 18 Desember 2004): "Ketika diperiksa ternyata surat berharga yang benar-benar ada hanya senilai Rp. 200,- (dua ratus) milyar. Padahal berdasarkan laporan keuangan per 30 April 2004, tertulis bahwa Bank Global memiliki surat berharga senilai Rp. 800,- (delapan ratus) milyar lebih hampir mendekati Rp. 900,- (sembilan ratus) milyar, terdapat selisih sekitar Rp. 600,- (enam ratus) milyar". Jadi obligasi yang dimiliki Bank Global memang tercatat di pasar modal namun hanya senilai Rp. 200,- (dua ratus) milyar.

Persoalan yang terdapat pada pasar obligasi ini adalah Emiten tidak transparan menerapkan sistem tata kelola perusahaan yang baik atau Good Corporate Governance. Pada saat membutuhkan pemeringkatan, 
emiten akan bersolek setengah mati agar kinerjanya kelihatan cantik. Kemudian beberapa bulan setelah obligasinya terjual mulai terdapat tanda-tanda credit risk dan liquidity risk. Pendapat Kahlil Rowter sebagai Kepala Mandiri Sekuritas bahwa dalam hal ini beliau mengharapkan Badan Pengawas Pasar Modal (BAPEPAM) untuk tidak menggunakan jasa peringkat dari lembaga pemeringkat atau rating company (Sapto Raharjo, 2003:99). Alasannya lembaga peringkat itu tidak mempunyai kekuasaan pada Emiten untuk memberikan datanya secara lengkap, akibatnya informasi peringkat selalu terlambat. (Kompas, edisi 1 Juni 2005)

Dalam kasus Bank Global, Sugeng Riyadi sebagai mantan Direktur Bursa Efek Surabaya mengusulkan peran wali amanat yang dalam hal ini dilakukan oleh Bank Niaga, agar BAPEPAM harus aktif memantau perjanjian perwaliamanatan itu (Jawa Pos, edisi 15 Mei 2003). Lebih lanjut dikatakan bahwa belum seriusnya peranan wali amanat dalam tugasnya akan memicu default atau gagal bayar pembayaran obligasi korporat. Dari pernyataan di atas jelas, terdapat kelemahan aparat yang mencakup integritas, profesionalisme dan kelemahan peraturan.

Adanya beberapa kelemahan instrument ini telah dimanfaatkan Direktur Bank Global yaitu Irawan Salim untuk membuat Laporan Keuangan tidak benar demi kepentingan dan keuntungan manajemen itu sendiri. Padahal berdasarkan Peraturan Badan Pengawas Pasar Modal (BAPEPAM) VIII.G.11 tentang Tanggungjawab Direksi atas Laporan Keuangan bahwa Direksi wajib membuat Surat Pernyataan bahwa isi laporan keuangan adalah benar dan atau tidak menyesatkan. Setelah mengetahui bahwa kondisi keuangannya tidak sehat kemudian menjual reksadana fiktif kepada pemodal khususnya nasabah, untuk membeli Reksadana Prudence Mantap. Di sisi lain menurut pendapat Fredy Rikson Saragih sebagai Kepala Biro Pengelolaan Investasi dan Riset BAPEPAM bahwa: (http://www.sinarharapan.co.id/ ekonomi/keuangan/2004/1213/keu2.html internet diakses tanggal 12 Mei 2005). "Kasus Bank Global menurutnya tidak terkait Reksadana Prudence Mantap yang diterbitkan oleh PT. Prudence Asset Manajemen. Lebih lanjut beliau mengatakan bahwa Reksadana Prudence Mantap tidak ada hubungannya dengan Bank Global. Reksadana ini dalam kondisi aman, tidak ada nasabah yang melapor kepada BAPEPAM dan redemption juga tidak terjadi”.

Hubungan Bank Global sebagai Agen Penjual dengan PT. Prudence Asset Manajemen sebagai Manajer Investasi dapat terjadi karena afiliasi kedua perusahaan tersebut sebagian besar sahamnya dimiliki oleh Irawan Salim dan istrinya. Dalam hal ini telah terjadi benturan kepentingan antara kepentingan perusahaan dengan kepentingan ekonomis pribadi direktur, komisaris, pemegang saham utama dengan perusahaan atau pihak terafiliasi.

Transaksi benturan kepentingan menurut Sri Indrastuti Hadiputranto adalah kontrak dalam rangka memberikan dan atau mendapatkan pinjaman, memperoleh atau melepaskan atau mempergunakan aktiva, jasa atau efek perusahaan atau perusahaan terkendali atau mengadakan kontrak perusahaan tersebut (Jurnal Hukum dan Pasar Modal, 2005:43). Peraturan mengenai transaksi ini terdapat dalam Pasal 82 ayat 3 Undang-Undang Penanaman Modal.

Pengaturan pelaksanaan transaksi benturan kepentingan sebagaimana diubah beberapa kali terakhir terdapat pada Keputusan Ketua BAPEPAM Nomer: KEP-32/PM/2000 tanggal 22 Agustus 2000 tentang Benturan Kepentingan Transaksi Tertentu atau Peraturan Nomer IX.E.1 bahwa: "Jika terjadi suatu transaksi dimana seorang direktur, komisaris, pemegang saham utama atau pihak terafiliasi dari direktur, komisaris atau pemegang saham mempunyai Benturan Kepentingan, maka transaksi dimaksud terlebih dahulu harus disetujui oleh pemegang saham independent atau wakil mereka yang diberi wewenang untuk itu dalam Rapat Umum Pemegang Saham sebagaimana diatur dalam peraturan ini. Persetujuan mengenai hal tersebut harus ditegaskan dalam bentuk akta notaris".

Tindakan BAPEPAM terhadap keberadaan transaksi benturan kepentingan sebagaimana fungsinya yaitu pembinaan, pengaturan, pengawasan seharihari di dalam kegiatan pasar modal pada dasarnya sesuai dengan UUPM Pasal 3 ayat 1. Juga BAPEPAM telah melaksanakan fungsi pengawasan yang dilakukan sehari-hari dalam kegiatan pasar modal sesuai dengan Pasal 4 UUPM bahwa: "Pembinaan, pengaturan, pengawasan sebagaimana dimaksud dalam Pasal 3 dilaksanakan oleh BAPEPAM dengan tujuan mewujudkan terciptanya kegiatan pasar modal yang teratur, wajar, efisien, serta melindungi kepentingan pemodal dan masyarakat".

\section{Analisa Kasus}

Perseroan terbatas adalah entitas bisnis yang penting dan banyak terdapat di dunia ini termasuk Indonesia. Kehadiran perseroan terbatas antara lain PT. Prudence Asset Manajemen atau Manajer Investasi dan PT. Bank Global International Tbk, sebagai salah satu kendaraan bisnis keuangan memberikan kontri- 
busi pada hampir semua kehidupan manusia. Dalam konteks istilah PT. Bank Global Internasional Tbk, kata perseroan menunjukkan pada modalnya yang terdiri dari sero atau saham. Sedangkan kata terbatas menunjuk pada tanggungjawab pemegang saham yang tidak melebihi nilai nominal saham yang dimilikinya. Dalam menjalankan kegiatannya suatu perseroan diwakili direksi atau agents yang ditunjuk oleh para pemegang saham/principal. Agents harus menggunakan keahlian, kebijaksanaan, itikad baik, tingkah laku yang wajar dan adil dalam memimpin perseroan.

Dalam praktek Bank Global timbul masalah karena adanya kesenjangan kepentingan antara para principal sebagai pemilik perusahaan dengan para manajemen sebagai agents. Pemilik mempunyai kepentingan agar dana yang diinvestasikan memberikan pendapatan yang maksimal, sedangkan pihak manajemen memiliki kepentingan terhadap perolehan insentif atas pengelolaan dana pemilik perusahaan.

Apabila lembaga keuangan tersebut dapat dikelola dengan baik sesuai prinsip-prinsip Good Corporate Governance dimana fungsinya sebagai financial intermediary berjalan baik. Pada akhirnya akan tercipta distribusi modal yang merata dan efisien sehingga menyediakan lapangan kerja (misal pemberian kredit melalui Usaha Kecil dan Menengah), meningkatkan kesejahteraan masyarakat dan memberikan kontribusi yang tidak sedikit untuk pembangunan ekonomi dan sosial masyarakat.

Pada saat ini bukanlah sesuatu yang sulit dilakukan dalam hubungan kerjasama antara Manajer Investasi dan Bank sebagai Agen Penjual. Hubungan erat tersebut dapat terjadi antara produk perbankan dengan reksadana, misalnya peranan Bank Standard Chartered dan Bank Commenwealth sebagai Agen Penjual. Dalam hal ini mereka menawarkan semua jenis reksadana sama seperti yang ditawarkan oleh beberapa Manajer Investasi, mulai dari Mees Pierson Finas Management, ABN Amro, Manulife dan sebagainya. Kedudukan agen penjual seperti demikian dinamakan supermarket reksadana.

Dalam praktek juga dikenal produk kolaborasi reksadana, antara lain PT. Mees Pierson Finas Investa Pesona bekerjasama dengan agen penjual yaitu PT. Bank Buana, PT. Bank Danamon, dan PT. Bank Niaga untuk menawarkan Fortis Pesona yaitu reksadana campuran. Kolaborasi Manajer Investasi dan Bank ini memang mewarnai hampir setiap usaha investasi reksadana. Jejak sukses kegiatan tersebut diikuti oleh banyak perbankan lainnya antara lain pihak PT. Bank Global Internasional Tbk seba- gai agen penjual mengajak teman satu concern atau kelompok usaha yaitu PT. Prudence Asset Manajemen untuk mengelola produk reksadana yang benarbenar dianggap dibutuhkan pasar.

\section{Mekanisme Penjualan Reksadana melalui Bank}

Gambar 1

Mekanisme Penjualan Reksadana melalui Bank

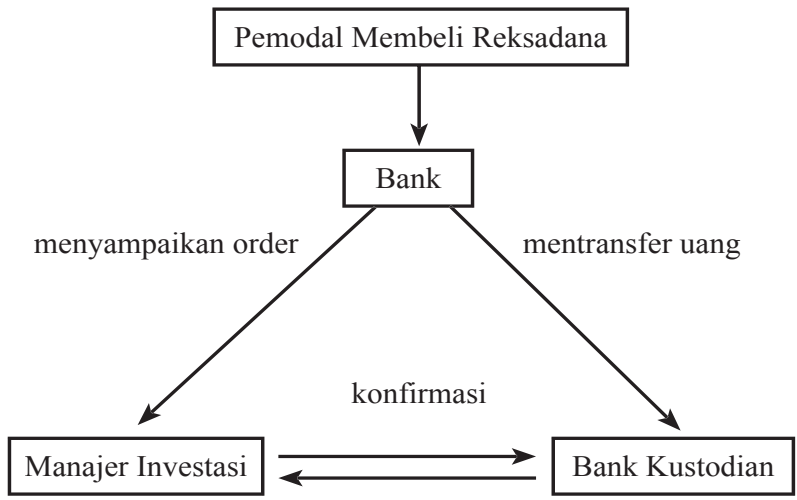

Hubungan kerjasama antara perbankan dan Manajer Investasi tersebut membuka peluang adanya persaingan usaha di antara produk sejenis. Problema rendahnya suku bunga, menyebabkan perbankan bersaing untuk mengumpulkan dana masyarakat dalam bentuk tabungan, deposito dan giro semakin ketat. Situasi ini membuat bank yang tidak pandai memanfaatkan sumber daya antara lain mengemas produk secara menarik akan ditinggalkan nasabah. Bank yang kalah bersaing akan menggunakan cara-cara ilegal dalam memasarkan produk yang sebenarnya hanya akan merugikan nasabah dan Bank itu sendiri. Perbuatan itu dilakukan dengan cara memasarkan produk deposito dalam kemasan reksadana. Hal itu dilakukan karena daya tarik reksadana lebih besar mengingat suku bunga yang ditawarkan lebih tinggi dibandingkan dengan deposito dan tabungan. Potensi penyelewengan semakin besar karena asimilasi antara produk perbankan dan produk pasar modal seperti reksadana semakin tidak kentara. Praktik di lapangan ada Bank dan Manajer Investasi yang menawarkan reksadana dengan jangka waktu 1, 3, 6, 12 mirip dengan deposito, saat ini belum ada ketentuan yang melarang praktik penjualan reksadana dengan jangka waktu seperti itu.

Sebenarnya perbankan diperbolehkan memasarkan reksadana karena di masa depan produk pasar modal dan produk perbankan akan terintegrasi. Semakin canggih teknologi, semakin membaur produkproduk dari lembaga keuangan yang berbeda-beda. Hal tersebut mengakibatkan semakin besar wilayah 
yang harus diantisipasi dengan aturan dan pengawasan yang ketat. Menurut pendapat Siti Sundari (wawancara tanggal Agustus 2007) bahwa: "Terdapat kekosongan hukum manakala terjadi pelanggaran pihak perbankan dalam pasar modal termasuk kriteria wilayah abu-abu. Maksudnya antara Bank Indonesia dan BAPEPAM memerlukan koordinasi lanjutan untuk menentukan jenis pelanggaran tersebut".

Kasus yang terjadi pada Bank Global mencerminkan aturan dan pengawasan yang lemah dari Bank Indonesia maupun BAPEPAM. Mereka seharusnya tidak hanya mengandalkan laporan keuangan semata, tetapi juga secara proaktif melihat produkproduk reksadana yang ditawarkan melalui perbankan. Alasannya Bank tidak harus melaporkan setiap produk reksadana yang ditawarkan pada Bank Indonesia maupun BAPEPAM.

Dari sisi otoritas pasar modal terdapat kelemahan pelaksanaan prinsip transparansi dilihat dari prosedur penjualan reksadana. Dalam rangka menawarkan produk Reksadana Prudence Mantap, sebagai sales maka Bank Global tidak memberikan penjelasan yang cukup kepada para pemodal mengenai bentuk reksadana tersebut. Para nasabah menjadi pemodal reksadana karena mendapatkan janji bunga reksadana melebihi suku bunga deposito. Fakta ini dapat dilihat dari kenyataan bahwa Bank Global memasarkan Reksadana Prudence Mantap tanpa memberikan tanda bukti Unit Penyertaan kepada pemodal. Akhirnya status Reksadana Prudence Mantap yang ditawarkan Bank Global tersebut dipertanyakan eksistensi dan juga kesesuaiannya dengan pengertian reksadana sebagaimana dimaksud UUPM.

Pelanggaran terhadap prinsip transparansi tersebut berhubungan dengan prinsip fairness yang juga merupakan salah satu pilar dari prinsip Good Corporate Governance. Prinsip fairness menghendaki terciptanya mekanisme kewajaran dan kejujuran yang baik dalam penyelenggaraan perusahaan. Seperti diberitakan, potensi penyelewengan pada Bank Global terjadi karena dalam kenyataannya Irawan Salim sebagai pemilik saham Bank itu juga pada PT. Prudence Asset Manajemen. Perbedaan kepentingan dalam mekanisme kewajaran dan kejujuran berkaitan kedudukan sebagai principal mayoritas menunjuk dirinya sendiri sebagai agents pada perusahaan sekuritas. Sesuai Keputusan BAPEPAM hal ini dinamakan dengan perbenturan kepentingan.

Pelanggaran terhadap prinsip prudent bahwa Bank Global yang berkedudukan sebagai agen penjual dituntut menjalankan kegiatan usahanya secara hati-hati. Diitinjau dari segi operasional pasar modal,
Bank Global wajib melaksanakan Keputusan BAPEPAM Nomor KEP-38/PM/2003 Peraturan Nomor: II.F.14 tentang Uji Kepatuhan Reksadana: “Apabila dalam memasarkan Reksadana, Manajer Investasi menggunakan Agen Penjual, Petugas Uji Kepatuhan harus memastikan Agen Penjual telah menerapkan prinsip-prinsip mengenal nasabah sebagaimana diatur dalam Peraturan Nomor V.D.10 tentang Prinsip Mengenal Nasabah.”

Kasus Reksadana Prudence, bahwa Bank Global sebagai agen penjual tidak menjalankan usaha dengan prinsip mengenal nasabah secara baik. Penjualan rekadana tersebut hanya bertujuan sematamata untuk mengeruk keuntungan sebesar-besarnya bagi manajemen Bank Global. Ketidaktaaatan Bank Global terhadap ketentuan perundang-undangan, khususnya berkaitan pengaturan reksadana menjadi bukti bahwa prinsip responsibility belum juga diterapkan dalam penyelenggaraan kegiatan usaha mereka.

Selain disebabkan lemahnya penerapan prinsip transparency, responbility, farness, juga karena salah dalam penerapan prinsip akuntabilitas. Prinsip ini menghendaki terciptanya mekanisme check and balances yang baik dalam penyelenggaraan perusahaan. Dalam kasus Bank Global sebagai agen penjual, banyak terdapat pelanggaran yang dilakukan direksi Bank Global mulai dari penjualan reksadana, rekayasa laporan keuangan dan lain-lain. Terjadinya pelanggaraan tersebut mengindikasikan bahwa mekanisme check and balances tidak berjalan secara baik.

\section{Perlindungan Pemodal Reksadana melalui Edukasi Publik}

Perkembangan pasar keuangan di negara-negara maju memberikan pengalaman yaitu semakin modern peradaban ekonomi suatu masyarakat, semakin besar peran pasar modal. Peran tersebut diikuti dengan semakin mengecilnya peran perbankan konvensional di dalam memobilisasi dana ke sektor produktif. Alasannya masyarakat yang semakin terdidik akan semakin tidak suka menanamkan dana mereka di bank konvesional. Karena bank konvensional memberikan return yang relatif kecil meskipun resikonya juga kecil.

Masyarakat yang faham akan pasar keuangan semakin mengerti akan penilaian serta pengendalian risiko investasi. Mereka akan semakin berani memasuki area yang lebih berisiko. Dengan memasuki pasar modal, mereka memasuki area yang lebih beresiko, menantang, dan mendorong pemanfaatan kemampuan analisis yang sudah dimilikinya, sekaligus mendapatkan return yang lebih tinggi. Pemodal 
di negara maju memiliki pemahaman yang lebih baik tentang perilaku masing-masing portopolio investasi. Menurut pendapat terdapat 5 (lima) perilaku sifat dari pemodal antara lain: 1. Value investors, seek stocks of companies priced below value; 2. Growth investors, seek stocks of companies whose near term growth indicates value, justifying current price; 3. Index investors, think the safety strategy is to buy stocks reprensenting substanly the whole market; 4. Technical investors, seek stocks that can be quickly sold and higher price; 5. Portopolio investors, believe that since price and value are identical, price measures risk, and investors should pick a mix of securities bearing the desired risk level. (Lawrence A. Cunningham, 2004:2)

Keberadaan perilaku tersebut menyebabkan banyak dana pemodal yang dapat mengalir ke sektor produktif melalui saham atau obligasi. Fenomena ini akan meningkatkan peran pasar modal yang diikuti dengan berkurangnya peran perbankan konvensional di dalam memobilisasi dana masyarakat ke sektor produktif. Kejadian seperti ini biasa disebut fenomena disintermediasi pasar keuangan.

Menarik untuk diperhatikan dengan mengambil contoh di Amerika Serikat bahwa pergeseran kegiatan memobilisasi dana masyarakat dari perbankan konvensional ke pasar modal ternyata dimotori oleh reksadana atau mutual fund. Pada tahun 1940 saat dimulainya pertumbuhan reksadana, hanya memiliki asset \$448 juta dengan 296 pemegang unit penyertaan. Kemudian tahun 1945 assetnya mencapai $\$ 1$ milyar dengan hampir 1.000 .000 pemegang unit penyertaan. Dua puluh tahun kemudian pada 1970 asset reksadana telah mencapai \$50 milyar dengan jumlah mencapai 400 reksadana. Pada tahun 1995 terdapat lebih dari 6.000 reksadana dengan total asset mencapai hampir $\$ 3$ triliun menangani hampir 40 juta pemodal. (Iggie H. Achsien, 2003:5)

Besarnya peran reksadana bagi pertumbuhan pasar modal di Amerika Serikat dapat dijadikan sebagai salah satu model dalam rangka mengantisipasi pertumbuhan reksadana Indonesia. Pertumbuhan reksadana Indonesia, diawali dengan terbatasnya pemahaman pemodal terhadap reksadana baik pengetahuan soal hukum dan risiko investasi maupun informasi mengenai Manajer Investasi. Apabila mereka akan membeli reksadana, hanya bertemu secara langsung dengan agen penjual. Namun agen penjual ternyata hanya memiliki pendidikan dan pemahaman yang minim terhadap lembaga ini. Mereka dengan kepandaian yang terbatas berusaha menawarkan reksadana dengan imbal hasil yang menggiurkan. Misalnya rek- sadana tidak pernah memberikan bunga namun agen penjual mengkonversi kenaikan NAB dengan bunga bank sebagai contoh: nilai NAB yang sebelumnya $100 \%$ naik menjadi $110 \%$ maka kenaikan $10 \%$ disetarakan dengan bunga. Disisi lain terdapat pula Agen Penjual reksadana yang merekayasa barang dagangan sehingga pemodal sulit membedakan produk pasar modal dan produk perbankan. Dalam hal ini dapat dicontohkan mereka menawarkan keuntungan tinggi berupa fixed income 3 persen tanpa menginformasikan resiko reksadana.

Padahal sesuai Keputusan BAPEPAM Nomor: KEP-19/PM/2004 dalam Peraturan Nomor: IV.D.1 bahwa iklan reksadana dilarang memuat: a. Informasi yang tidak benar atau tidak mengungkapkan fakta materiil; b. Kata atau kalimat memberikan kesan bahwa pemodal tidak akan rugi: c. Kesan bahwa pemodal memperoleh untung tanpa adanya resiko; d. Gambaran, proyeksi, janji atas kinerja reksadana masa mendatang; e. Kalimat-kalimat seperti "belilah sekarang juga", "jangan ketinggalan", "bertindaklah sekarang" dengan maksud menarik minat calon pemodal.

Minimnya pengetahuan pemodal dan Agen Penjual menyebabkan pertumbuhan pasar reksadana di Indonesia rentan terhadap penarikan tunai oleh para pemodal. Sifat pemodal reksadana yang menyebabkan penarikan tunai antara lain: a. Perilaku penabung, menurut pendapat Abiprayadi Riyanto, bahwa mereka hanya menginginkan keamanan dan stabilitas saja, belum bisa menerima risiko. Dengan polosnya investor menyatakan, namanya saja reksadana pendapatan tetap, maka wajar saja harus menyuguhkan pendapatan dan return yang tetap pula. Padahal berinvestasi adalah proses menabung yang berorientasi pada tujuan tertentu dan bagaimana mencapai tujuan yang diharapkan. Semua keinginan di masa mendatang sangat mungkin dicapai kalau dilakukan dengan perencanaan keuangan dan tentunya lebih baik dibanding menabung (Kompas, edisi 29 Juni 2005), dan b. Perilaku pedagang, menurut pendapat Eko Priyo Pratomo, President Direktur PT. Fortis Investment Indonesia bahwa mereka masih menurut saja apa kata Agen Penjual manakala menguntungkan. Sebagian pemodal memindahkan investasinya ke reksadana lain atau ke deposito atas ajakan Agen Penjual bukan atas pemahaman dan keputusan sendiri. Mereka beranggapan bahwa apapun metode yang dipakai Manajer Investasi harus memberikan return yang tinggi. Akibatnya perilaku investor reksadana lebih seperti perilaku pedagang daripada investor. (Kompas, 1 Juni 2005) 
Adanya perilaku yang dilakukan pemodal tersebut merupakan wujud dari penerimaan sumber-sumber pendapatan disesuaikan dengan pengeluaran keuangan. Pengeluaran pemodal pada dasarnya dapat diklasifikasikan sebagai anggaran modal atau capital dan anggaran rutin atau current. Anggaran rutin dimaksudkan sebagai pembelanjaan berbagai macam keperluan hidup, sedangkan anggaran modal diartikan penyertaan sejumlah dana untuk investasi dan diharapkan dapat menghasilkan pendapatan di kemudian hari.

Hubungan keuangan antara kedua anggaran tersebut, dikaitkan dengan perilaku penabung dan perilaku pedagang dalam berinvestasi, bahwa mereka melaksanakan anggaran modal atau capital dengan harapan dapat menghasilkan pendapatan agar dapat dimanfaatkan sewaktu-waktu. Apabila anggaran tersebut tidak dipergunakan maka dianggap sebagai sumber pendapatan untuk menutup kebutuhan anggaran rutin atau current.

Cara pendekatan yang dilakukan para pemodal seperti ini, tidak sesuai dengan prinsip investasi reksadana. Menurut pendapat Naresh Krishnan bahwa: (Majalah Swa: edisi 15/XXI, halaman 90) "Saya tidak panik terhadap nasib reksadana yang kena ekses negatif dari situasi pasar yang bearish. Belajar dari pengalaman bahwa investasi reksadana harus jangka panjang jika ingin membukukan keuntungan optimal". Dengan demikian, pada prinsipnya perkembangan reksadana di beberapa negara nyaris sama. Perkembangannya ditentukan: a. kepiawaian manajer investasi dalam mengelola portopolio; b. pengaruh dari keadaan ekonomi global; c. stabilitas keamanan negara yang bersangkutan; d. kondisi sektor industri itu sendiri.

Jadi investasi reksadana pada prinsipnya untuk jangka menengah dan panjang. Pemodal yang membutuhkan dana jangka pendek atau kurang dari satu tahun, maka lebih cocok menempatkan dana pada produk pasar uang seperti tabungan maupun deposito. Dalam rangka membangun kembali paradigma reksadana sebagai alternatif investasi maka diperlukan peningkatan education public bagi pemodal reksadana. Sebagai perbandingan di Amerika Serikat bahwa sekolah menjadi agen strategis dalam memperkenalkan reksadana bagi anak-anak dan remaja. Para Manajer Investasi menyisihkan sebagian pendapatannya untuk market education. Mereka berusaha meyakinkan orangtua agar memilih reksadana sebagai penjamin masa depan anak-anak mereka kelak 5, 10, bahkan 20 tahun kemudian. Karena tujuan investasi sendiri bukan hanya long term tetapi very long term.
Reksadana tersebut memasukkan saham-saham perusahaan yang dikenal anak-anak dan remaja seperti Robecco Group yang menerbitkan reksadana Young Dinamic berisi saham-saham Nike, Nintendo, Tamagochi. (Ubaidillah, 2004:54)

Demikian pula dengan keadaan di Australia sebagaimana pernyataan Simon Brewis Weston, President Direktur Commenwealth Bank of Australia bahwa: (Kompas, 8 Desember 2004) "Kami berpendapat, meningkatkan kemampuan financial seseorang merupakan proses panjang. Semakin tinggi pengetahuan financial seseorang, makin rendah kemungkinan mereka tidak mendapatkan pekerjaan. Studi mengungkapkan bahwa dengan meningkatkan pengetahuan financial sederhana pada sekolah-sekolah khususnya kelas 7 hingga 12 akan berpotensi meningkatkan ekonomi Australia sebesar 6 miliar dollar per tahun melalui penciptaan 16.000 lapangan kerja baru. Keuntungan yang mengalir dari peningkatan kemampuan angkatan kerja dalam masalah keuangan akan meningkatkan produktifitas, meningkatkan tabungan nasional, dan menciptakan konsumen yang mengerti betul akan hak-haknya. Murid-murid SMU di Distrik Sheffield Tasmania yang lingkungannya peternakan dan pertanian mengajukan program mengenai keuangan pertanian. Topik yang dipelajari dalam kursus 11 pekan antara lain bagaimana berinvestasi mutual fund setelah mendapatkan hasil pertanian".

Disisi lain berkaitan dengan urgensi tanggungjawab education publik, peranan BAPEPAM sesuai pendapat Freddy Rikson Saragih, Kepala Biro Pengelolaan Investasi dan Riset BAPEPAM bahwa (Kompas, edisi 1 Juni 2005): "Edukasi terhadap investor bukanlah keahlian BAPEPAM. Dalam hal ini yang dilakukan BAPEPAM adalah membuat peraturan dan menerapkannya dengan tegas dan tidak melakukan standar ganda."

Terkait dengan pernyataan tersebut, peranan BAPEPAM lebih condong menjalankan political interest policy daripada public policy. Karena reksadana menyangkut dana publik, dalam rangka membangun kembali kepercayaan masyarakat maka integritas BAPEPAM diletakkan pada tataran sebagai regulator. Sesuai Pasal 3 ayat 1 UU PM bahwa pembinaan, pengaturan, pengawasan sehari-hari kegiatan pasar modal dilakukan oleh Badan Pengawas Pasar Modal (BAPEPAM). Dalam hal ini pembuatan aturan disertai penegakan hukum, terukur tanpa pandang bulu merupakan wujud penerapan asas transparansi dan responsibility.

Wujud penerapan asas ini oleh Manajer Investasi sebagai tanggungjawab education publik masih 
berupa pembuatan produk-produk reksadana yang memuat slogan-slogan pembangunan. Misalnya Prestasi Gebyar Indonesia, Bangun Indonesia, Semesta Obligasi Indonesia, Cerdas yaitu diambil dari nama-nama reksadana yang diterbitkan Schroeder Investment MGT, Nikko Securities, Semesta Indovest, Lippo Investment, dan Mees Pierson Finas Investment Management.

\section{PENUTUP}

\section{Kesimpulan}

Pasar modal merupakan sarana pertemuan penjual dan pembeli memperdagangkan efek misalnya saham maupun obligasi sebagai sumber nilai ekonomis dari reksadana. Agar nilai reksadana dari Manajer Investasi berharga tinggi maka efek tersebut harus bagus, dalam hal ini Emiten dituntut secara terusmenerus untuk memacu usahanya dengan makin baik melalui penerapan prinsip GCG yang meliputi transparansi, akuntabilitas, fairness, independency, dan responsibility. Sebaliknya jika prinsip GCG tidak dilaksanakan secara baik maka pemodal reksadana tidak terlindungi hak-haknya. Dari contoh kasus PT. Bank Global terdapat kelemahan penerapan GCG berupa adanya benturan kepentingan antara kepemilikan saham dalam bidang usaha perbankan dan usaha sekuritas atau Manajer Investasi. Terhadap pelanggaran pasar modal berkaitan prinsip GCG maka BAPEPAM-LK mengenakan: sanksi administratif berupa peringatan tertulis, denda, pembatasan kegiatan, pembekuan kegiatan usaha, pencabutan ijin usaha, pembatalan persetujuan dan pembatalan pendaftaran dan sanksi perdata berupa pemberian sesuatu ganti rugi. Sedangkan Bank Indonesia, akhirnya mencabut ijin operasional Bank Global tanggal 13 Januari 2005.

\section{Rekomendasi}

Dalam rangka perlindungan nasabah reksadana maka secara preventif BAPEPAM-LK dan Manajer Investasi perlu melaksanakan edukasi pada pemodal. Alasannya mereka sulit menilai apakah produk yang dibeli sudah sesuai ketentuan yang benar. Jika Bank selain menjual reksadana sekaligus juga merangkap sebagai penerbit maupun pengelola reksadana yang sama maka pemodal harus meragukan reksadana tersebut. Bagi pemerintah c.q. BAPEPAM diperlukan pengawasan secara preventif aktif dengan cara membekukan perijinan produk reksadana yang tidak sehat. Hal ini dapat dilaksanakan dengan cara input rating produk reksadana yang dibuat oleh biro rating independen.

\section{DAFTAR PUSTAKA}

\section{Buku:}

Achsien, Iggie H., 2003, Investasi Syariah di Pasar Modal, Jakarta: Gramedia Pustaka Utama.

Balfas, Hamud M., 2006, Hukum Pasar Modal Indonesia, Jakarta: Tatanusa.

Boediono, 2001, Indonesia Menghadapi Ekonomi Global, Yogyakarta: BPFE-UGM.

Cunningham, Lawrence A., 2004, What is Value Investing, New York: MC Graw-Hill.

Nugraha, Ubaidillah, 2004, Secangkir Teh Hangat Pasar Modal, Jakarta: Gramedia Pustaka Utama.

Rahardjo, Sapto, 2003, Panduan Investasi Obligasi, Jakarta: Gramedia Pustaka Utama.

Retnadi, Djoko, 2005, Obligasi Rekapitulasi Perbankan, Jakarta: Masyarakat Profesional Madani.

\section{Surat Kabar:}

Kompas, Melek Finansial Sejak Muda, edisi 8 Desember 2007.

Kompas, Saatnya Beralih ke Reksadana Saham, 29 Juni 2005.

Kompas, Cakrawala Investasi Pemodal Mesti Diperpanjang, edisi 1 Juni 2005.

Kompas, Terlibat Kasus Bank Global Disidik BAPEPAM, edisi 18 Desember 2004.

Jawa Pos, Pembekuan Bank Global, edisi 17 Desember 2004.

Jawa Pos, Polri Kontak Singapura dan Malaysia, edisi 16 Desember 2004.

Jawa Pos, BI Bekukan Bank Global, edisi 14 Desember 2004.

Jawa Pos, BES Atur Wali Amanat, edisi 15 Mei 2003.

http://www.sinarharapan.co.id/ekonomi/keuangan/ 2004/1213/keu2.html internet diakses tanggal 12 Mei 2005.

Wawancara dengan Siti Sundari, Direktur Penyidikan Kantor Bank Indonesia, telah dilakukan pada tanggal 27 Agustus 2007.

Jurnal Hukum dan Pasar Modal, Reksadana Fiktif dan Obligasi Subordinasi Bank Global, edisi 2 Juli 2005, halaman 86.

Jurnal Hukum dan Pasar Modal, Transaksi Benturan Kepentingan Sebuah Perbandingan, edisi pertama, HKPM, Januari, 2005.

Majalah Swa, Berburu Reksadana Saham ke Negeri Cina, edisi 15/XXI, 21 Juli-3 Agustus 2005. 